JINOTEP 5 (1) Oktober (2018): 1-7

JINOTEP (Jurnal Inovasi Teknologi Pembelajaran)

Kajian dan Riset Dalam Teknologi Pembelajaran

http://journal2.um.ac.id/index.php/jinotep/index

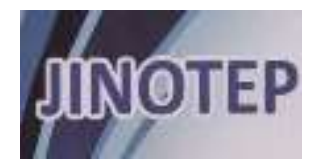

\title{
DESAIN PEMBELAJARAN BERBASIS NETWORK \\ LEARNING DALAM KETERAMPILAN MENULIS MATA \\ PELAJARAN BAHASA INGGRIS KELAS X SMA N 02 KOTA KEDIRI
}

Dewi Menur, Punaji Setyosari, Saida Ulfa

Teknologi Pembelajaran, Universitas Negeri Malang

\section{Article History}

Received: Sept 19, 2018

Accepted: March 22, 2019

Published:March 23, 2019

\section{Keywords}

Network Learning Keterampilan Menulis Bahasa Inggris Teks Deskriptif

\begin{abstract}
Abstrak
Dalam perkembangan teknologi sesuai dengan karakteristik siswa perlunya desain pembelajaran berbasis Network Learning (pembelajaran jejaring). Pada pembelajaran ini siswa aktif berinterasi dalam memberikan informasi secara kolaborasi. Adanya keterampilan menulis yang dapat dilakukan sesuai perkembangan teknologi berpengaruh dengan keaktifan siswa dalam berkomunikasi maupun berinteraksi dengan memberikan kontekn penulisan yang baik dan benar. Pada mata pelajaran Bahasa Inggris siswa dapat melakuakan pembelajaran menggunakan Network Learning yang mana siswa dapat memberikan penngetahuan mengenai teks deskriptif kepada siswa lainnya dan sisiwa lainnya dapat memberikan komen mengenai hasil yang mereka posting melalui media Instagram.
\end{abstract}

\begin{abstract}
In the development of technology in accordance with the characteristics of students the need for instructionaldesign of Network Learning. In this learning students actively interact in providing information to collaboration. The existence of writing skills that can be done according to technological developments influence the students activeness in communicating and interacting by providing a good writing contexts and true. In English subjects students can do learning using Network Learning which students can provide insight into descriptive text to other students and other side can give comments about the results they post through Instagram.
\end{abstract}

Corresponding author :

Dewi Menur

Teknologi Pembelajaran

Pascasarjana Universitas Negeri Malang

Jalan Semarang 5 Malang E-mail: dewimenur@gmail.com
2018 Universitas Negeri Malang p-ISSN 2406-8780 e-ISSN 2654-7953 


\section{PENDAHULUAN}

Bahasa Inggris merupakan bahasa International yang digunakan sebagai sarana komunikasi yang telah diterapkan dalam kurikulum di Indonesia. Sesuai kurikulum 2013, mata pelajaran Bahasa Inggris adalah salah satu mata pelajaran wajib pada jenjang Sekolah Menengah Pertama (SMP/MTS) maupun Sekolah Menengah ke Atas (SMA/MAN/SMK). Bahasa Inggris memiliki empat keterampilan (skills), melipuri speaking, listening, reading, dan writing. Mata pelajaran Bahasa Inggris dipelajari agar siswa mempunyai pengetahuan mengenai Bahasa Inggris sebagai sarana/wadah berkomunikasi maupun berinteraksi terhadap warga negara asing. Bahasa Inggris mempunyai berbagai macam materi yang mana dengan tujuan siswa mendapatkan pengetahuan mengenai dasar dari konsep Bahasa Inggris dari grammar (tata bahasa), conversation (percakapan), maupun jenis-jenis text. Materi yang diajarkan sesuai dengan silabus dengan konsep sesuai Rancangan Pelaksanaan Pembelajaran (RPP) yang dilaksanakan oleh guru dalam proses belajar mengajar di kelas. Akan tetapi, keterampilan menulis dalam mata pelajaran perlunya rancangan yang lainnya sesuai dengan pengelaman siswa pada kehidupan.

Keterampilan menulis diberikan oleh siswa sesuai dengan RPP yang disajikan guru. Keterampilan menulis merupakan salah satu keterampilan dalam bahasa inggris yang meyediakan teks dalam uraian pembelajaran. keterampilan menulis merupakan "ultimate goal" atau kompetensi utama yang hendak dituju bagi pelajar (Wijayatiningsih \& Mulayadi, 2012). Keterampilan menulis digunakan dalam materi jenis-jenis text, salah satunya teks deskriptif. Pada materi teks deskriptif (descriptive text) mengunakan keterampilan menulis sebagai materi pembelajaran dalam Bahasa Inggris. Teks deskriptif merupakan cara untuk menggambarkan atau menggambarkan objek, orang atau ide sehingga pembaca dapat melihat objek, atau orang, atau ide secara
fisik(Dirgeyasa, 2016). Akan tetapi, kemampuan menulis dapat melatih penulisan siswa menggunakan Bahasa Inggris. Pada era globalisasi, semua sosial media menggunakan penulisan untuk dapat memberikan pengetahuan yang baru. Pengaruh keterampilan menulis juga berpengaruh dalam konteks pembelajaran siswa dalam menulis dimanapun mereka mengapresiasikan pengetetahuan yang dimiliki. Proses melakukan keterampilan menulis ini dapat dilakukan dengan waktu yang cukup singkat dalam membantu proses pembelajaran dan memanfaatkan sosial media yang digunakan oleh siswa sehingga dapat menerapkan keterampilan menulis menggunakan Bahasa Inggris. Perkembangan teknologi, khususnya sosial media merupakan salah satu media atau sarana berkomunikasi di dunia maya. Sosial media disebut juga sebagai Social Network Sites (SNS) memiliki berbagai macam situs yang disebut juga sebagai sosial media, khususnya kalangan remaja. Sebuah social media yang digunakan untuk berinteraksi, menyebarkan dan mendapatkan informasi (Gustina, 2015). Sehingga dapat membantu siswa dalam mengimplementasikan pengetahuan yang mereka dapatkan ke dalam kehidupan yang dijadikan sebagai pengelaman dalam proses belajar.

Pada hasil observasi, keterampilan menulis di SMA N 02 Kota Kediri belum mencakupi adanya keterampilan menulis dengan menkorelasikan pengalaman belajar siswa dengan memanfaatkan teknologi sesuai perkembangan jaman. Tugas yang diberikan oleh guru sesuai rancangan pembelajaran menuntut siswa untuk mengerjakan secara tradisional sedangkan keaktifan terhadap sosial media siswa lebih mempunyai waktu yang sangat banyak. Sehingga proses belajar mengajar hanya bergantung pada tingkat kehadiran siswa, siswa hanya mendapatkan pengetahuan melalui sekolah saja. Akan tetapi, sesuai perkembangan teknologi, sosial media memberikan dampak negatif maupun positif. Agar siswa memiliki kemampuan yang positif maka pembelajaran dengan memberikan tugas- 
tugas sesuai dengan keefektifan siswa dalam menggunakan sosial media yang mana mereka lebih condong menggunakan teknologi daripada pembelajaran secara traditional.

Pada penelitian ini, sosial media dijadikan sebagai media dalam rancangan pembelajaran dalam keterampilan menulis dengan memanfaatkan teknologi sesuai dengan kebutuhan siswa. Rancangan pembelajaran ini berbasis Network Learning (Pembelajaran Jejaring) yang mana memanfaatan sosial media dalam melatih keterampilan menulis dan siswa dalam dunia pendidikan dan pengalaman kehidupan sehingga terhindar dari unsur SARA. Berbagai sosial media telah digunakan oleh kalangan remaja, maka proses pembelajaran seharusnya juga mengikuti sesuai perkembangan jaman yang dibutuhkan oleh siswa. Network Learning merupakan pembelajaran yang digunakan untuk memberikan koneksi: antara satu pelajar dan pelajar yang lainnya; antara peserta didik dan tutor; antara komunitas belajar dan sumber belajarnya (Goodyear, Banks, Hodgson, \& McConnell, 2004). Sehingga interaksi juga dapat terjadi dimanapun dan kapanpun serta pengeetahuan yang didapat berdasarkan berbagi pengetahuan hasil yang mereka bagikan menggunakan akun sosial media masingmasing akan terhubung satu sama lainnya.

Rancangan pembelajaran ini menggunakan model ASSURE yang mana memanfaatkan teknologi sebagai proses belajar mengajar di kelas. Pengembang model ASSURE merencanakan secara sistematis untuk pemanfaatan teknologi dan media dan pengajaran yang efektif di ruang kelas (Smaldino, Lowther, \& Russell, 2011). Adanya model rancangan pembelajaran yang memanfaatkan teknologi dalam mendukung pembelajaran di era ini membantu siswa dalam memperbaiki proses mendapatkan pengetahuan baru dan pengetahuan yang telah mereka pelajari secara kolaborasi. Model ini juga dapat digunakan secara asyncronous (belajaran dengan waktu yang sama) dan syncronous (belajar dengan waktu yang berbeda) sehingga proses yang dapat digunakan terlihat di dalam kelas.
Rancangan pembelajaran berbasis network learning melatih keterampilan menulis siswa dimanapun dan kapanpun dapat melakukan interaksi secara kolaboasi yang mana memanfaatkan sosial media, khusunya Instagram yang diminati oleh para kalangan remaja. Instagram adalah aplikasi berbasis visual dimana teks bersifat opsional dan jika digunakan, melayani fungsi deskriptif atau kontekstual(Budge, 2017). Instagram dapat membantu dalam memfasilitasi dalam penugasan ketrampilan menulis, khususnya teks deskriptif. Penggunaan teks deskriptif mempunyai karakter yang sama dalam memanfaat sosial media. dengan kelebihan Instagram yang mana sebuah foto sebagai icon, kemudia adanya desktipsi (caption yang buat untuk sebuag foto), dan kolom komentar, like, maupun share (berbagi). Kategori ini memberikan kemudahan dalam membagikan pengetahuan secara visual. Teks deskriptif merupakan cara dalam menggambarkan secara visual apa yang kita lihat berupa objek yang ada, seperti sesuatu objek, tempat, maupun seseorang secara detail. Sehingga siswa dapat menerapkan tugas yang diberikan guru melalui foto yang mereka unggah di Instagram menggunakan caption mengenai foto tersebut sesuai dengan karakteristik teks deskriptif.

Rancangan pembelajaran berbasis network learning dalam keterampilam menulis kelas X SMA N 02 Kota Kediri memberikan inspirasi baru kepada guru dalam merancanga pembelajaran. Keterampilan menulis yang dimiliki siswa setelah mendapatkan pembelajaran di dalam kelas dengan memanfaatkan Instagram memberikan tanggapan positif kepada siswa yang menunjang hasil belajar siswa. Setelah adanya pembelajaran di dalam kelas yang mana guru menujukan materi mengenai teks deskriptif dan contoh yang diberikan telah di unggah melalui akun Instagram guru kemudian siswa melalukan interaksi di kolom komen tersebut. Kemudian setelah diberikan contoh teks deskriptif ke dalam Instagram, siswa diberikan tugas untuk mengunggah konten foto dengan caption sesuai dengan karakteristik teks deskriptif ke dalam akun media mereka masing- 
4 JINOTEP (Jurnal Inovasi dan Teknologi Pembelajaran) Kajian dan Riset dalam Teknologi Pembelajaran Vol. 5, No. 1, Oktober 2018, Hal. 1-7

masing. Setelah siswa mengunggah di akun mereka masing-masing, teman sebaya dan guru memberi komentar mengenai hasil keterampilan menulis sesuai dengan karakteristik teks deskriptif.

\section{METODE}

Model penelitian ini menggunakan jenis penelitian dan pengembangan $(\mathrm{R} \& \mathrm{D})$. Penelitian pengembangan ini menggunakan model ASSURE dalam menetapkan langkahlangkah pengembangan desain pembelajaran. Pada penelitian dan pengembangan ini menggunakan model ASSURE karena pada model pengembangan ini merupakan suatu model prosedural dalam mengembangkan rancangan pembelajaran di dalam kelas dengan memanfaatkan teknologi yang telah ada sehingga mempermudah proses belajar mengajar di keals begitu juga pada penerapan yang siswa dengan pengetahuan yang mereka miliki sehingga terjadinya network learning.

Tahapan model pengembangan ASSURE ini memiliki enam tahapan yang dilakukan dalam melakukan penelitian dan pengembangan ini. Enam tahapan pada model ASSURE adalah (1) menganalisis pebelajar, (2) menentujan tujuan pembelajaran atau kompetensi, (3) memilih metode, media, dan materi, (4) menggunakan media dan materi, (5) mendorong partisipasi pebelajar, serta (6) mengevaluasi dan memperbaiki.

Tahapan yang pertama, menganalisis pebelajar yang mana sisiwa kelas X IPS di SMA N 02 Kota Kediri tahun ajaran 2018/2019. Pada tahapan ini, sisiwa mempunyai karakteristik umum, kemampuan dasar, dan gaya belajar. Karakteristik umum para siswa ini sering menggunakan gadget (smartphone) dalam melakukan aktifitas dimanapun dan kapanpun mereka berada. Dengan mereka menggunakan gadget mereka cenderung membuka aplikasi Instagram yang hanya bisa digunakan melalui gadget mereka. Sehingga kemampuan dasar siswa sangat ahli menggunakan aplikasiInstagram dan merespon secara tertulis apabila terjadinya proses komunikasi pada media tersebut. Serta gaya belajar siswa dengan menggabungkan teknologi memberikan motivasi terhadap karya personal siswa.

Tahap selanjutnya adalah tahap menentukan tujuan pembelajaran dan kompetensi yang mana sesuai dengan kurikulum 2013 dalam kompetensi dasar yang telah tercantum. Namun, pada penelitian pengembangan ini, memiliki tujuan berdasarkan pedoman silabus mata pelajaran Bahasa Inggris yang mana siswa bisa berpikir kritis dalam memberi komentar terhadap siswa lainnya, kemudian dengan menggunakan media Instagram siswa bisa membuat tulisan mengenai teks deskrpitif melalui tugas yang telah diberikan.

Kemudian tahap memilih metode, media, dan materi yang mana pemilihan sesuai dengan topik penelitian ini. Perkembangan siswa yang mana metode pembelajaran berpusat pada siswa sehingga menggunakan latihan dan praktik dalam keterampilan menulis, dengan pemilihan media Instagram serta pemilihan materi teks deskriptif sesuai dengan pemanfaatan Instagram. Pemilihan metode, media, dan materi mempunyai korelasi satusama lain agar pembelajaran bisa terlaksana sesuai dengan kebutuhan siswa.

Setelah pemilihan media dan materi maka adanya tahap menggunakan media dan materi. Pada tahap ini terbagi menjadi lima kategori (1) mengulas teknologi, media, dan material; (2) menyiapkan teknologi, media, dan material; (3) menyiapkan teknologi, media, dan material; (4) menyiapkan para pebelajar; serta (5) memberikan pengalaman belajar. Penelitian ini menggunakan media Instagram sesuai dengan materi teks deskriptif yang digunakan dalam keterampilan menulis. Instagram yang dijadikan sebagai media protofolio elektronik untuk menggungah hasil ketermpilan menulis teks deskriptif yang dapat menjadi acuan pada teks deskriptif. Setelah siswa mengunggah foto dengan karakteristik teks deskriptif maka siswa lainnya dapat memberikan komentar di dalam akun sosial media siswa lainnya. Siswa lainnya 
mengomentari postingan yang telah diunggah di akun mereka sendiri.

Tahap selanjutnya mendorong partisipasi pebelajar. Instagram memacu untuk aktivitas siswa dalam mengunggah hasi kerja mereka ke dalam akun Instagram mereka dan bagaimana siswa memberikan tanggapan kepada siswa lainnya, seperti memberikan komentar hasil tulisan siswa lainnya. Aktivitas dan tanggapan siswa yang diberikan pengetahuan di sekolah kemudian diberikannya tugas (protofolio elektronik) sehingga bisa tugas tersebut menjadi bahan tanggapan yang diajarkan sesuai pengelaman siswa.

Tahapan terakhir adalah mengevaluasi dan memperbaiki. Pada tahap ini pentingnya pencapaian nilai siswa dalam nilai akhir dan refleksi siswa. Setelah melakukan kegiatan dan penilaian pentinganya merevisi hasil respons siswa terhadap penilaian sehingga proses belajar mengajar yang dilakukan melalui network learning dapat berjalan dengan baik.

\section{HASIL}

Hasil penelitian dan pengembangan ini memberikan produk rancangan pembelajaran berbasis netrowk learning dalam keterampilan menulis mata pelajaran Bahasaa Inggris Kelas X SMA N 02 kota Kediri. Produk pengembangan berupa sistem pembelajaran yang menggunakan network learning sesuai dengan kebutuhan siswa di era ini dan melatih keterampilan menulis agar mempermudah perlajaran dan memberikan waktu yang singkat dalam sebuah pelajaran. Pada penelitian ini, produk pengembangan berbasis network learning didasari dengan kebutuhan siswa yang mana siswa juga memiliki banyak aktifitas sehingga ada beberapa orang yang tidak mengikuti pelajaran. Pada sistem pembelajaran ini mempermudah pengetahuan siswa agar bisa mendapatkan pelajaran dengan menggunakan media Instagram yang menjadi sosial media populer di kalangan remaja. Pengetahuan yang siswa dapatkan dengan cara membagi pengetahuan mereka menggunakan teks deskriptif kepada siswa lainnya dan terjadi interaksi secara tertulis pada kolom komentar yang menjadi fitur Instagram.

\section{Deskripsi Produk}

Produk yang dihasilkan dari penelitian dan pengembangan ini adalah sebuah rancangan sistem pembelajaran berbasis network learning. Pada pembelajaran ini, model rancangan pengembangan menggunakan model ASSURE yang mana merancangan keterampilam menulis dengan memanfaatkan teknologi, khususnya sosial media (Instagram). Dimana kalangan remaja lebih menyukai konten Instagram secara visual. Produk ini memberika fasilitas dimana siswa belajar secara kolaborasi sehingga keterampilan menulis tidak hanya terjadi secara tatap muka, melainkan siswa harus berpikir kritis dalam pengetahuan yang mereka miliki.

Pengembangan sistem pembelajaran ini sangat menyenangkan dalam aktifitas seharihari untuk dilakukan oleh siswa kelas X mata pelajaran Bahasa Inggris SMA N 02 Kota Kediri karena siswa telah memiliki akun Instagram dan mereka menggunakannya dimanapun dan kapanpun mereka berada. Siswa juga bisa berbagi pengetahuan kepada teman yang lainnya. Setelah siswa beraktifitas menggunakan Instagram dengan menggunakan Bahasa Inggris, siswa akan terlatih dalam menulis menggunakan Bahasa Inggris sesuai kaidah grammar (tata bahasa).

\section{Penyajian Data Hasil Uji Coba Produk dan Uji Efektifitas Produk}

Penelitian ini mengukur tingkat kevalidan dalam rancangan pembelajaran berbasis network learning. Pengukuran kevalidan melalui angket yang diberikan kepada ahli desain, ahli materi, dan audiens. Instrumen pengumpulan pada penelitian ini menggunakan angket (questionnaire), daftar cocok (checklist) atau pedoman wawancara, lembar observasi dan lain sebagainya (Arikunto, 2011). Pada validasi ahli desain dilakukan untuk menguji tingkat kevalidan desain pembelajaran yang telah dikembangkan. Dan validasi ahli materi dilakukan untuk menguji tingkat kevalidan materi yang terdapat di dalam proses pembelajaranan network learning. Sedangkan validasi terhadap audien 
6 JINOTEP (Jurnal Inovasi dan Teknologi Pembelajaran) Kajian dan Riset dalam Teknologi Pembelajaran Vol. 5, No. 1, Oktober 2018, Hal. 1-7

terbagi menjadi 3 langkah, yaitu: uji coba perorangan, uji coba kelompok kecil dan uji coba lapangan.

Pertama, validasi yang dilakukan oleh ahli desain pada rancangan pembelajaran berbasis network learning. Berdasarkan dari penilaian ahli desain sebesar $92 \%$ sehingga dikategorikan valid. Selain itu, pengembang juga mendapatkan penilaian penilaian kualitatif dari ahli desain yang berupa masukan dan saran mengenai produk yang dikembangkan seperti rancangan berbasis network learning seharusnya diberikan pada awal pembelajaran hingga akhir pembelajaran itu berlangsung.

Kedua, validasi yang dilakukan oleh ahli materi pada rancangan pembelajaran berbasis network learning. Berdasarkan dari penilaian ahli materi sebesar $83 \%$ sehingga dikategorikan valid.

Ketiga, pada tahap ini merupakan uji audiens yang terbagi menjadi tiga uji coba. Pada uji coba perorangan kepada siswa kelas X SMA N 02 Kota Kediri. Uji coba perseorangan yang dilakukan dengan 3 siswa dengan hasil sebesar $84 \%$ dan termasuk dalam kategori valid.

Keempat, pada tahap ini pengembang melakukan uji coba kelompok kecil kepada siswa kelas X SMA N 02 Kota Kediri. Uji coba kelompok kecil dilakukan dengan 9 siswa dengan hasil sebesar $86 \%$ dan termasuk dalam kategori valid.

Kelima, pada tahap ini pengembang melakukan uji coba lapangan. Pada uji coba lapangan kepada siswa kelas X SMA N 02 Kota Kediri. Uji coba lapangan menggunakan 26 siswa dengan hasil sebesar $87 \%$ dan termasuk dalam kategori valid.

\section{Revisi Produk}

Penelitian ini juga mempunyai revisi produk yang diperoleh dari ahli desain dan ahli materi. Pada penelitian ini mengatur kelayakan desain pembelajaran berbasis network learning, pengembang mengumpulkan beberapa data yang diperoleh dari ahli desain, ahli materi dan siswa dalam uji coba perorangan, kelompok kecil dan uji lapangan. Ahli desain, ahli materi dan siswa memberikan beberapa masukan agar proses belajar mengajar melalui produk yang dikembangkan menjadi valid dan layak digunakan dalam keterampilan menulis Bahasa Inggris. Saran yang diberikan oleh para ahli dan audiens menjadi bahan bagi pengembang dalam merevisi produk desain pembelajaran berbasis network learning.

Hasil yang diperoleh dari saran ahli desain yang mana menampakan kemunculan network learning dalam proses pembelajran bukan hanya dijadikan protofolio elektronik saja, ahli materi memberikan saran agar kosa kata yang digunakan sesuai dengan teks deskriptif dan siswa memberikan saran yang mana proses pembelajaran menggunakan Instagram menarik tetapi beberapa orang enggan meposting menggunakan Instagram dengan alasan mereka belum mengetahui grammar dengan baik dan benar. Revisi ini digunakan pengembang berfungsi untuk sistem pembelajaran yang diterapkan dalam kelas memberikan keefektifan pembelajaran dan kecepatan mengingat pengetahuan dengan adanya pengalaman belajar.

\section{PEMBAHASAN}

Berdasarkan uji kevalidan dan kelayakan desain pembelajaran berbasis network learning memiliki hasil analisis yang valid dari ahli desain, ahli materi, dan para siswa. idapati hasil analisis dari ahli medi dan ahli materi dan tanggapan dari audiens. Ketiga subjek memberikan hasil valid sehingga proses belajar mengajar di dalam kelas dan penugasan yang diberikan berjalan sesuai dengan rancangan pembelajaran.

Saran yang diberikan oleh para ahli kemudian di revisi agar penindakan dalam rancangan pembelajaran berjalan sesuai rancangan tersebut. Proses network learning digunakan untuk melatih kemampuan menulis secara praktik siswa sehingga siswa memiliki pengalaman denga keterampilan menulis. Materi yang digunakan adalah teks deskriptif yang mencakup grammar, seperti present tense. Guru mengajarkan atau memberikan pengenalan terhadap teks deskriptif kemudian 
diberikannya contoh teks deskriptif yang telah diposting oleh guru melalui akun Instagram guru. Kemudian di kelas, siswa melihat contoh dari teks deskriptif melalui akun Instagram masing-masing siswa. Masing-masing siswa memliki smartphone sendiri untuk akun Instagram yang telah mereka miliki. Pada era globalisasi ini, siswa di SMA N 02 Kota Kediri diperbolehkan membawa smartphone untuk menunjang proses belajar mereka dalam mencari pengetahuan. Setelah siswa mendapatkan pengetahuan mengenai teks deskriptif kemudian siswa diberikan tugas (protofolio elektronik) yang mana masingmasing siswa memposting foto dengan caption mengenai teks deskriptif dengan judul sesuai karakeristik teks tersebut. Setelah siswa memposting maka siswa lainnya bisa memberikina komentar. Dalam hal ini, siswa memiliki pengalaman dalam pelajaran teks deskriptif dengan melakukan latihan dan praktik maka siswa dapat belajar sesuai pengalaman belajar mereka.

\section{SIMPULAN DAN SARAN Simpulan}

Produk yang dihasilkan pada penelitian ini berupap desain pembelajaran berbasis network learning dalam keterampilan menulis mata pelajaran Bahasa Inggris kelas X SMA N 02 Kota Kediri. Rancangan pembelajaran yang digunakan dalam network learning dapat mempermudah siswa dalam melakukan pengalaman menulis pada akun sosial media yang mereka miliki, khususnya Instagram. Produk rancangan pembelajaran ini memberikan alokasi waktu yang sangat singkat pada proses belajar karena adanya latihan dan praktik pada keterampilan menulis. Siswa tidak jenuh dalam menulis mengenai hasil belajar mereka. Dan media yang dimiliki fleksibel dan dapat diakses dimana saja dan kapan saja dengan berbagai jaringan.

\section{Saran}

Desain pembelajaran berbasis network learning ini dapat dimanfaatkan dalam keterampilan menulis. Akan tetapi, perlunya jaringan internet, khusunya wifi sehingga siswa dengan mudah mengakses pembelajaran dengan mudah. Tidak semua siswa memiliki jaringan internet sedangkan pada era ini membuthkan jaringan internet dalam memperoleh informasi. Saran pada desain pembelajaran ini tidak luput pada kekurangan yang mana sistem pembelajaran tidak hanya dilakukan di dalam kelas tetapi bisa menggunakan pembelajaran secara online dan tidak terpaku dalam kelas saja. Kemudian media yang digunakan bisa menggunaakn media lainnya sesuai dengan perkembangan jaman dan karakteristik siswa.

\section{DAFTAR RUJUKAN}

Arikunto, S. 2011. Penelitian Tindakan Kelas. Jakarta:Bumi Aksara.

Budge, K. 2017. Objects in Focus: Museum Visitors and Instagram. Wiley Periodicals, Inc , Volume 60 Number 1

Dirgeyasa, I. W. (2016). College Academic Writing A Genre - Based Perspective. Jakarta: KENCANA

Gustina, H. (2015). Korelasi Media Sosial Instagram dengan Presentasi Diri Mahasiswa Jurusan Ilmu Komunikasi Universitas Riau. Jom FISIP Volume 2 No. 2 .

Goodyear, P., Banks, S., Hodgson, V., \& McConnell. (2004). Advances in research on network learning. Dordrecht: Kluwer Academic Publishers

Smaldino, S. E., Lowther, D. L., \& Russell, J. D. (2011). Instructional Technology and Media for Learning Edisi Ke-9. Jakarta: Kencana

Wijayatiningsih, T.D., \& Mulayadi, D. (2012). Penerapan Strategi Simatic Maping untuk Meningkatkan Keterampilan Menulis Teks report Bagi Mahasiswa Ilmu Keperawatan Unimus. Jurnal.unimus.as.is, 353-362. 